\title{
BENTONIT TERAKTIVASI ASAM SULFAT SEBAGAI ADSORBEN DALAM PEMURNIAN PELUMAS BEKAS
}

\author{
Tiva Lathifah ${ }^{1)^{*}}$, Nia Yuliani ${ }^{2)}$ dan Gladys Ayu PKW ${ }^{3)}$ \\ ${ }^{1)}$ PT Sucofindo SBU Laboratorium \\ Jl. Arteri Tol Cibitung No.1, Cibitung, Cikarang Barat, Bekasi 17520 \\ ${ }^{2)}$ Progam Studi Biologi FMIPA Universitas Nusa Bangsa \\ Jl. KH Sholeh Iskandar KM 4 Cimanggu Tanah Sereal, Bogor 16166 \\ ${ }^{2)}$ Progam Studi Kimia FMIPA Universitas Nusa Bangsa \\ Jl. KH Sholeh Iskandar KM 4 Cimanggu Tanah Sereal, Bogor 16166 \\ *e-mail: tiva.lathifah@gmail.com
}

\section{ABSTRACT \\ Activated Bentonits of Sulfatic Acid as Adsorben in Purchase of Used Lubricants}

\begin{abstract}
Recycling of used lubricating oil is one of the alternatives in the framework of efficiency, saving oil consumption, and reducing pollution. One effort to purify used lubricating oil is to separate impurities through the adsorption method. The adsorbent that can be used is bentonite. Activation of bentonite using acid will produce adsorbent with an active side and greater surface acidity so that the adsorption ability is higher than before activated. Characteristics of lubricating oil produced are: kinematic viscosity $40{ }^{\circ} \mathrm{C}$ and $100{ }^{\circ} \mathrm{C}$ at $109.94 \mathrm{cSt}$ and 14.57 cSt recently; viscosity index is 136; specific gravity $15^{\circ} \mathrm{C}$ is 0.8872 ; and the resulting color is L5.0. Activated sulfonic bentonite can be an optimum adsorbent in purifying used lubricating oil, with optimum bentonite concentration is $30 \%$ and optimum adsorption temperature is $70{ }^{\circ} \mathrm{C}$ resulting in a $49 \%$ increase in viscosity efficiency of $40^{\circ} \mathrm{C}$ and $30.79 \%$ for temperatures of $100^{\circ} \mathrm{C}$.
\end{abstract}

Keywords: Bentonite, Lubricants, Adsorption

\begin{abstract}
ABSTRAK
Daur ulang minyak pelumas bekas merupakan salah satu alternatif dalam rangka efisiensi, penghematan konsumsi minyak bumi, serta mengurangi pencemaran. Salah satu upaya menjernihkan minyak pelumas bekas adalah dengan memisahkan zat-zat pengotor melalui metode adsorpsi. Adsorben yang dapat digunakan adalah bentonit. Aktivasi bentonit menggunakan asam akan menghasilkan adsorben dengan sisi aktif dan keasaman permukaan yang lebih besar sehingga kemampuan adsorpsinya lebih tinggi dibandingkan dengan sebelum diaktivasi. Karakteristik minyak pelumas yang dihasilkan yaitu: viskositas kinematik $40{ }^{\circ} \mathrm{C}$ dan $100{ }^{\circ} \mathrm{C}$ sebesar $109,94 \mathrm{cSt}$ dan $14,57 \mathrm{cSt}$ secara berturut-turut; indeks viskositas sebesar 136; specific gravity $15{ }^{\circ} \mathrm{C}$ sebesar 0,8872 ; serta warna yang dihasilkan adalah L5,0. Bentonit teraktivasi asam sulfat mampu menjadi adsorben yang optimum dalam pemurnian minyak pelumas bekas, dengan konsentrasi bentonit optimum adalah $30 \%$ dan suhu adsorpsi optimum adalah $70{ }^{\circ} \mathrm{C}$ menghasilkan \% efisiensi kenaikan viskositas sebesar $49,15 \%$ untuk suhu $40{ }^{\circ} \mathrm{C}$ dan $30,79 \%$ untuk suhu $100{ }^{\circ} \mathrm{C}$.
\end{abstract}

Kata kunci : adsorpsi, bentonit, pelumas

\section{PENDAHULUAN}

Minyak pelumas digunakan dalam perawatan mesin kendaraan bermotor, kendaraan diesel, mesin industri, mesin kapal, dan sebagainya yang berfungsi untuk mengurangi gesekan dan keausan dua permukaan logam yang saling bersentuhan. Minyak pelumas bekas atau yang dalam kesehariannya disebut juga dengan oli bekas, pada dasarnya adalah minyak pelumas yang dalam pemakaiannya telah mengalami berbagai macam gesekan, dan tercampur dengan kotoran dari komponenkomponen mesin, sisa pembakaran maupun debu. Hal ini menyebabkan efektivitas minyak pelumas menurun (Mara dan Kurniawan, 2015). Pelumas bekas merupakan material yang mudah terbakar dan juga tergolong limbah yang dapat 
mencemari lingkungan. Menurut Mukhlishoh (2008), pelumas bekas merupakan limbah B3 karena dapat menyebabkan tanah menjadi tandus dan kehilangan unsur haranya. Pelumas bekas juga dapat mencemari perairan karena tidak dapat larut dalam air.

Salah satu metode yang digunakan dalam pemurnian pelumas bekas yaitu menggunakan asam kuat dan adsorben. Lianna et al. (2012) telah menggunakan batu bara, arang aktif dan silika gel sebagai adsorben dalam pemurnian pelumas bekas. Adsorben lain yang dapat digunakan untuk mengadsorpsi pengotor dalam minyak pelumas bekas adalah bentonit. Bentonit memiliki kemampuan terbesar dalam proses pemurnian minyak pelumas bekas dibandingkan dengan arang aktif dan zeolit (Kusumah, 2013). Bentonit juga mudah didapatkan di alam. Sebelum digunakan sebagai adsorben, bentonit diaktivasi terlebih dulu untuk meningkatkan daya jerapnya (Hilyati dan Widihastono, 1991). Dalam penelitian ini, bentonit yang teraktivasi diharapkan dapat digunakan dalam pemurnian minyak pelumas kendaraan mesin diesel. Oleh karena itu, perlu dilakukan variasi konsentrasi bentonit dan suhu adsorpsi dalam pemurnian minyak pelumas bekas. Kemurnian minyak pelumas bekas ditentukan berdasarkan karakteristik minyak pelumas yang dihasilkan berupa viskositas kinematik, indeks viskositas, specific gravity, dan warna yang dihasilkan.

\section{BAHAN DAN METODE}

\section{Bahan dan Alat}

Bahan yang digunakan dalam penelitian ini adalah minyak pelumas bekas Meditran SX SAE $15 \mathrm{~W}-40 \mathrm{CH}-4$ (minyak pelumas mesin diesel berbahan bakar solar) yang diperoleh dari salah satu bengkel kendaraan, Ca-bentonit (dirancang untuk pemurnian minyak kelapa sawit, minyak kelapa, dan minyak kernel sawit) yang diperoleh dari salah satu perusaahaan pemasok bentonit di kota Bogor, $\mathrm{H}_{2} \mathrm{SO}_{4}$ (p.a.), akuades, toluena, metanol, dan aseton.

Alat-alat yang digunakan adalah neraca analitik, hot plate, peralatan gelas, labu semprot, termometer, oven, screen mesh 100, syringe, tisu, spidol serta instrumen Fourier Transform Mid-IR Spectrometer Agilent Technologies Carry 630 (FTIR), Viscometer Bath Stanhope Setta KV-8, Density Meter Analyzer Anton Paar DMA 4500M, dan Colorimeter Analis P526.

\section{Metode}

Penelitian terdiri dari preparasi dan aktivasi bentonit, preparasi sampel pelumas bekas, pemurnian dengan metode adsorpsi dengan variasi konsentrasi bentonit dan suhu adsorpsi. Kemudian dilanjutkan pengolahan data dan interpretasi. Data yang diperoleh dibandingkan dengan data sebelum pemurnian dan spesifikasi minyak pelumas tersebut.

\section{Preparasi dan Aktivasi Bentonit (Mahmudha dan Irwan, 2015)}

Bentonit yang digunakan dalam penelitian ini diayak menggunakan screen mesh 100, selanjutnya bentonit dikarakterisasi menggunakan FTIR pada bilangan gelombang $300-4000 \mathrm{~cm}^{-1}$. Aktivasi bentonit dilakukan dengan cara mengambil sebanyak 200 gram bentonit lalu ditambahkan $200 \mathrm{~mL}$ larutan $\mathrm{H}_{2} \mathrm{SO}_{4} 5 \mathrm{~N}$, kemudian diaduk selama 3 jam dengan kecepatan $100 \mathrm{rpm}$ pada suhu $70^{\circ} \mathrm{C}$. Hasil dari pengadukan didinginkan, kemudian disaring dengan penyaring vakum dan dicuci dengan akuades panas sampai terbebas dari ion sisa asam.

Bentonit yang telah diaktivasi kemudian dikeringkan dalam oven pada suhu $100-110^{\circ} \mathrm{C}$ selama 3 jam. Setelah kering, bentonit teraktivasi diayak menggunakan screen mesh 100. Selanjutnya bentonit teraktivasi asam dikarakterisasi menggunakan FTIR pada bilangan gelombang $300-4000 \mathrm{~cm}^{-1}$.

\section{Preparasi Sampel Pelumas Bekas (Joseph, 2010)}

Sampel pelumas bekas disiapkan sebanyak 1,2 L dimasukkan ke dalam gelas piala, kemudian diaduk dengan kecepatan $100 \mathrm{rpm}$ dan ditambahkan $240 \mathrm{~mL} \mathrm{H}_{2} \mathrm{SO}_{4}$ (p.a). Campuran terus diaduk selama 3 jam hingga diperoleh larutan yang homogen, lalu didiamkan selama 24 jam hingga terbentuk 2 lapisan. Lapisan atas dipisahkan dengan menggunakan corong pisah untuk proses penjernihan selanjutnya.

\section{Pemurnian dengan Metode Adsorpsi}

Bentonit dan sampel dicampurkan dengan memvariasikan bobot bentonit yaitu 10, 20, dan 30 gram, serta memvariasikan suhu adsorpsi yaitu 25, 50, dan $70{ }^{\circ} \mathrm{C}$. Lama waktu pengadukan 3 jam (100 rpm). Pada masingmasing tahap diberikan waktu lama pengendapan selama 24 jam. Konsentrasi bentonit dan suhu yang ditambahkan diformulasikan seperti pada Tabel 1 . 
Tabel 1. Formulasi Konsentrasi Bentonit dan Suhu Adsorpsi

\begin{tabular}{cccc}
\hline \multirow{2}{*}{ Konsentrasi Bentonit } & \multicolumn{3}{c}{ Suhu Adsorpsi $\left({ }^{\circ} \mathrm{C}\right)$} \\
\cline { 2 - 4 } & T25 & T50 & T70 \\
\hline B10 & B10T25 & B10T50 & B10T70 \\
B20 & B20T25 & B20T50 & B20T70 \\
B30 & B30T25 & B30T50 & B30T70 \\
\hline
\end{tabular}

Keterangan:

$\mathrm{T} 25$ = Suhu adsorpsi $25^{\circ} \mathrm{C}$

$\mathrm{T} 50=$ Suhu adsorpsi $50^{\circ} \mathrm{C}$

$\mathrm{T} 70=$ Suhu adsorpsi $70^{\circ} \mathrm{C}$
$\mathrm{B} 10=$ Bentonit 10 gram dalam $100 \mathrm{~mL}$ sampel $\mathrm{B} 20=$ Bentonit 20 gram dalam $100 \mathrm{~mL}$ sampel $\mathrm{B} 30=$ Bentonit 30 gram dalam $100 \mathrm{~mL}$ sampel

\section{Pengujian Karakteristik Minyak Pelumas Bekas Setelah Adsorpsi Bentonit}

Sampel minyak pelumas bekas yang telah dimurnikan dengan berbagai variasi konsentrasi bentonit dan suhu pengadukan kemudian diuji karakteristiknya, yaitu: viskositas kinematik, indeks viskositas, specific gravity, dan warna yang dihasilkan. Pengujian viskositas kinematik mengacu pada metode standar ASTM D445-15 (2017), indeks viskositas mengacu pada metode standar ASTM D2270-10 (2016), specific gravity mengacu pada metode standar ASTM D4052-15 (2017), dan warna mengacu pada metode standar ASTM D1500-12 (2017). Hasil pengujian dibandingkan dengan sampel uji sebelum dilakukan pemurnian dan spesifikasi minyak pelumas tersebut.

\section{Pengukuran Viskositas Kinematik (ASTM D 445-15)}

Viscometer bath, lampu, pemanas, dan stirer dinyalakan. Suhu diatur sesuai dengan suhu pengujian yang diinginkan yaitu $40{ }^{\circ} \mathrm{C}$. Sampel dimasukkan ke dalam viskometer ostwald sampai tanda batas. Setelah itu bagian luar viskometer dibersihkan dengan tisu. Lubang pipa sampel ditutup dengan karet penutup. Viskometer yang berisi sampel tersebut kemudian dipasang klem dan dimasukkan ke dalam viscometer bath. Setelah suhu yang dikehendaki stabil, sampel dibiarkan selama 30 menit di dalam bath. Kemudian karet penutup viskometer dibuka dan diukur waktu alir dengan menggunakan stop watch, yaitu dari garis A sampai B, dan dari garis B ke C. Kekentalan kinematik diukur dengan waktu alir minimum 200 detik. Nilai kekentalan diperoleh dari hasil kali laju alir dengan faktor viskometer. Pengukuran juga dilakukan pada suhu $100{ }^{\circ} \mathrm{C}$. Setelah selesai, viskometer dikeluarkan dan viscometer bath dimatikan kembali.

\section{Perhitungan Indeks Viskositas (ASTM D2270-10)}

Hasil pengukuran viskositas kinematik pada suhu $40{ }^{\circ} \mathrm{C}$ dan $100{ }^{\circ} \mathrm{C}$ digunakan untuk mendapatkan nilai indeks kekentalan (VI) pada suhu $40{ }^{\circ} \mathrm{C}$ dan $100{ }^{\circ} \mathrm{C}$.

\section{Pengukuran Specific Gravity (ASTM D4052-11}

Alat, printer, stabilizer, dan density meter dihidupkan, kemudian dipilih metode Lubricant. Data sampel dimasukkan di sample list. Lalu dipilih OK dan di klik Main Screen. Sampel (sekitar $2 \mathrm{~mL}$ ) dimasukkan ke dalam tabung osiloskop yang bersih dan kering dengan menggunakan syringe yang sesuai. Tabung osiloskop dipastikan tidak ada gelembung yang terperangkap. Sampel yang akan diinjeksikan dipastikan bebas dari gelembung-gelembung kecil kemudian tombol start ditekan. Setelah kondisi valid, hasil terprint dengan sendirinya. Pengukuran duplo dilakukan dengan cara yang sama, kemudian alat dibersihkan dengan pelarut yang sesuai yaitu toluena dan aseton, hingga osiloskop bersih dan kering. Setelah pemakaian selesai, alat density meter, stabilizer, printer, dan alat dimatikan kembali.

\section{Pengukuran Warna (ASTM D1500-12)}

Sejumlah sampel dimasukkan ke dalam tabung uji warna hingga tanda batas. Tabung uji tersebut dimasukkan ke dalam alat kolorimeter. Alat kolorimeter dinyalakan, standar warna diputar hingga tercapai persamaan warna sampel dengan standar. Skala warna yang tertera pada alat kemudian dicatat sebagai warna sampel. Setelah selesai pengujian, tabung uji dibersihkan dari sampel. Kemudian alat di matikan kembali.

\section{Pengolahan Data dan Interpretasi}

Berdasarkan data hasil analisis pemurnian minyak pelumas dengan bentonit teraktivasi asam sulfat, maka hasil pengujian dibandingkan 
dengan sampel uji sebelum dilakukan pemurnian dan spesifikasi minyak pelumas tersebut.

\section{HASIL DAN PEMBAHASAN}

\section{Aktivasi Bentonit}

Aktivasi bentonit menggunakan $\mathrm{H}_{2} \mathrm{SO}_{4}$ bertujuan untuk melarutkan komponenkomponen seperti $\mathrm{Fe}_{2} \mathrm{O}_{3}, \mathrm{Al}_{2} \mathrm{O}_{3}, \mathrm{CaO}$, dan $\mathrm{MgO}$ yang mengisi ruang antarlapisan bentonit, sehingga akan menambah luas permukaan adsorben dan akan lebih banyak sisi aktif yang terdapat pada bentonit. Selanjutnya ion-ion $\mathrm{Ca}^{2+}$ dan $\mathrm{Mg}^{2+}$ yang berada pada permukaan kristal adsorben secara berangsur-angsur digantikan oleh ion $\mathrm{H}^{+}$dari $\mathrm{H}_{2} \mathrm{SO}_{4}$ (Komadel, 2003).

Menurut Purwaningsih (2002), reaksi yang terjadi pada saat bentonit diaktivasi dengan asam adalah sebagai berikut :

$$
\begin{gathered}
\mathrm{Al}_{2} \mathrm{O}_{3} \cdot 2 \mathrm{SiO}_{2} \cdot 2 \mathrm{H}_{2} \mathrm{O}+3 \mathrm{H}_{2} \mathrm{SO}_{4} \rightarrow \mathrm{Al}_{2}\left(\mathrm{SO}_{4}\right)_{3} \\
+2 \mathrm{SiO}_{2}+5 \mathrm{H}_{2} \mathrm{O}
\end{gathered}
$$

Aktivasi bentonit menggunakan asam akan menghasilkan adsorben dengan sisi aktif lebih besar dan keasaman permukaan yang lebih besar. Oleh karena itu, kemampuan adsorpsinya lebih tinggi dibandingkan dengan sebelum diaktivasi, sehingga memudahkan dalam proses adsorpsi.

Pengujian FTIR digunakan untuk memastikan bahwa bentonit telah teraktivasi $\mathrm{H}_{2} \mathrm{SO}_{4}$. Identifikasi dilakukan dengan cara melihat keberadaan gugus-gugus fungsional pada struktur bentonit. Bentonit mengandung mineral montmorillonit sebesar 80-85\%. Interpretasi data yang dihasilkan hanya bersifat kualitatif, karena hanya menampilkan keberadaan gugus-gugus fungsional pada senyawa. Identifikasi terhadap gugus-gugus fungsional bentonit, dapat diketahui melalui hasil puncak serapan pada spektra FTIR. Pitapita serapan yang khas akan muncul pada bilangan gelombang $3620,1 \mathrm{~cm}^{-1}$ gugus $-\mathrm{OH}$; $1636,4 \mathrm{~cm}^{-1} \mathrm{H}-\mathrm{O}-\mathrm{H} ; 1035,7 \mathrm{~cm}^{-1}$ dan $794,6 \mathrm{~cm}^{-1}$ Si-O; $530 \mathrm{~cm}^{-1}$, dan $468,7 \mathrm{~cm}^{-1}$ menunjukkan bahwa salah satu mineral penyusun bentonit adalah montmorillonit (Tan, 1982). Spektrum FTIR bentonit dapat dilihat pada Gambar 1 . Interpretasi spektrum FTIR dapat dilihat pada Tabel 2.

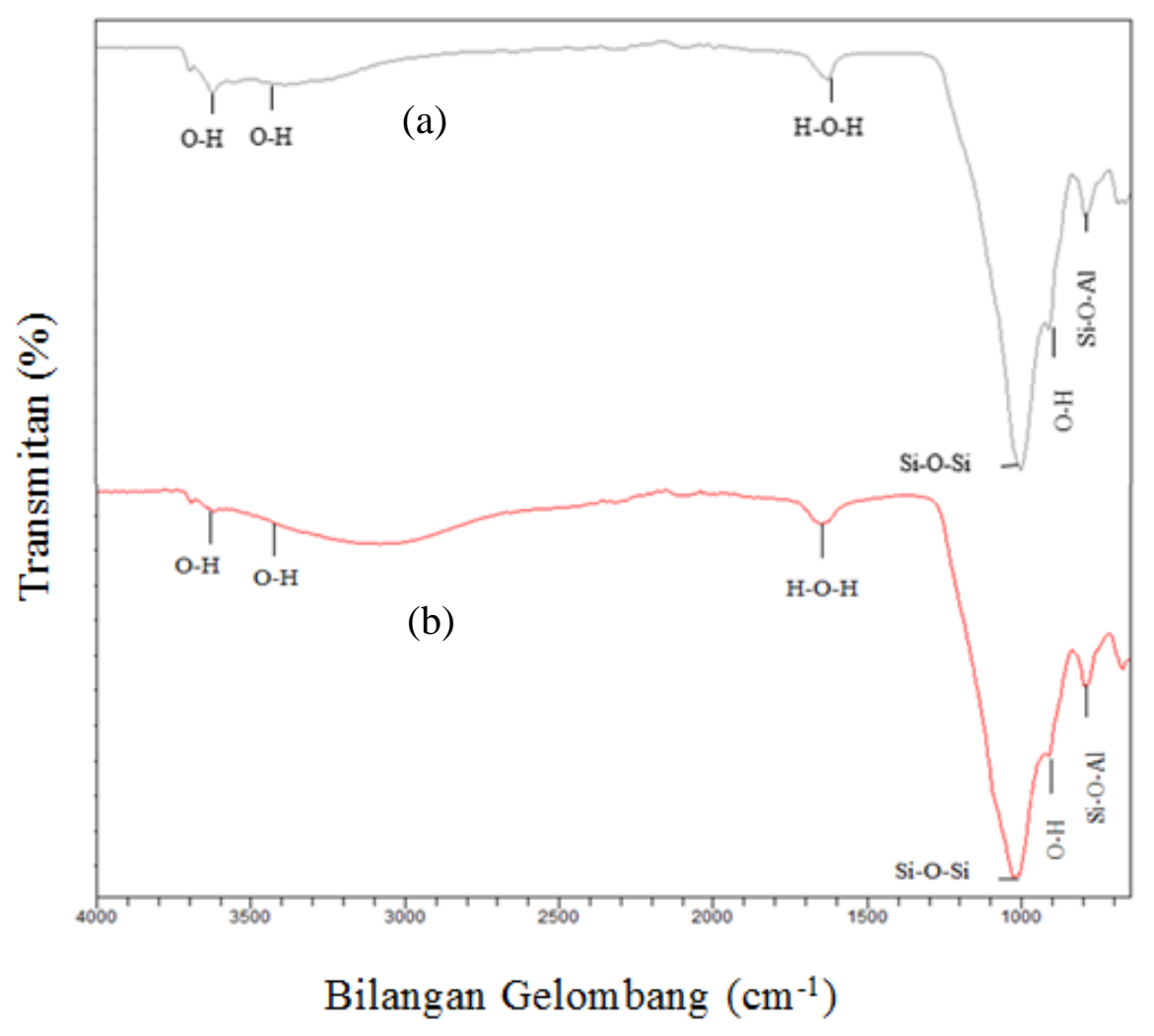

Gambar 1. Spektrum Bentonit Sebelum Aktivasi (a) dan Bentonit Teraktivasi Asam Sulfat 5 N (b) 
Tabel 2. Interpretasi Spektrum FTIR

\begin{tabular}{lll}
\hline No & Bilangan Gelombang $\left(\mathrm{cm}^{-1}\right)$ & Jenis Vibrasi \\
\hline 1. & 3626,17 & Ulur O-H (gugus hidroksil yang terikat pada Al di lapisan \\
2. & 3441,01 & oktahedral Al-Al-OH atau Mg-OH-Al) \\
3. & 1635,64 & Ulur gugus OH yang terhidrasi molekul air yang teradsorbsi \\
4. & 1033,85 & Tekuk dari H-O-H dari air yang teradsorpsi didalam bentonit \\
5. & 918,12 & Ulur asimetris dari Si-O \\
6. & 794,67 & Tekuk gugus hidroksil dari Al-OH-Al \\
\hline
\end{tabular}

Berdasarkan spektrum FTIR pada Gambar 1. terlihat bahwa terdapat perubahan nilai bilangan gelombang pada spektrum bentonit dan bentonit teraktivasi asam. Masing-masing spektra memiliki puncak serapan yang hampir sama, hanya saja ada beberapa puncak serapan yang mengalami pergeseran bilangan gelombang, yaitu bilangan gelombang 3441,01 $\mathrm{cm}^{-1}$ yang merupakan vibrasi ulur $\mathrm{OH}$ dari $\mathrm{H}_{2} \mathrm{O}$, mengalami pergeseren menjadi $3425,58 \mathrm{~cm}^{-1}$ pada bentonit teraktivasi $\mathrm{H}_{2} \mathrm{SO}_{4} \quad 5 \quad \mathrm{~N}$. Selanjutnya pada bilangan gelombang 1033,85 $\mathrm{cm}^{-1}$ yang merupakan vibrasi ulur asimetris dari Si-O mengalami pergeseran menjadi 1041,56 $\mathrm{cm}^{-1}$ pada bentonit teraktivasi $\mathrm{H}_{2} \mathrm{SO}_{4} 5 \mathrm{~N}$. Hal tersebut menunjukan bahwa bentonit telah teraktivasi.

\section{Pemurnian Pelumas Bekas dengan Penambahan Asam}

Pemurnian minyak pelumas bekas yang dilakukan dengan penambahan asam (acid treatment) membentuk endapan. Endapan tersebut berupa kontaminan karbon dan asam sulfat yang membentuk larutan garam dan terendap ke dasar larutan. Namun, dari proses tersebut masih terdapat sisa dari kontaminan karbon yang tidak ikut terendap, sehingga menghasilkan warna yang masih gelap. Hasil pemurnian minyak pelumas dengan asam sulfat dapat dilihat pada Gambar 2.

Minyak pelumas terdiri dari senyawasenyawa hidrokarbon, yaitu parafin, naften, senyawa aromatik dan sejumlah kecil senyawa organik yang mengandung oksigen dan belerang yang dipandang sebagai pengotor (Harjono, 2001). Minyak pelumas yang telah digunakan dalam waktu cukup lama akan mengalami perubahan komposisi atau susunan kimia, selain itu juga akan mengalami perubahan sifat fisik maupun mekanis. Hal ini disebabkan karena pengaruh tekanan dan suhu selama penggunaan, dan juga kotoran-kotoran yang masuk ke dalam minyak pelumas itu sendiri. Kontaminan yang biasa terdapat dalam pelumas bekas adalah logam-logam akibat keausan elemen (tembaga, besi, kromium, alumunium, timah, molibdenum, silikon, nikel atau magnesium), kotoran atau jelaga, bahan bakar, air, produk sampingan pembakaran, etilen glikol, dan produk-produk asam/ belerang (Anton, 1985).

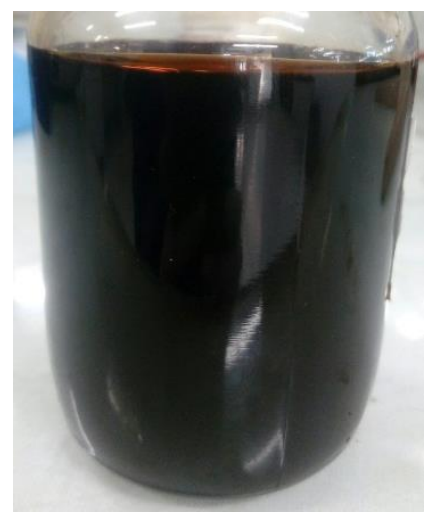

(a)

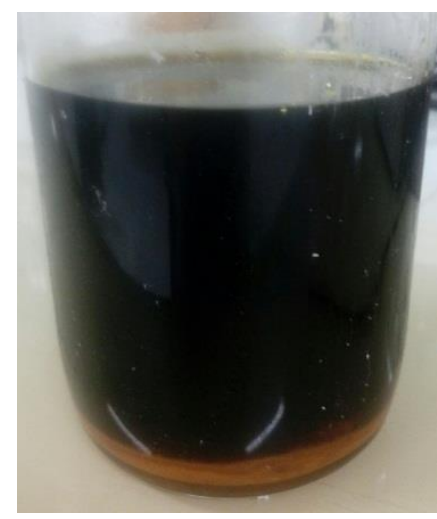

(b)

Gambar 2. Minyak Pelumas Bekas Sebelum Pemurnian dengan Asam (a) dan Minyak Pelumas Bekas Setelah Pemurnian dengan Asam (b) 
Menurut Mara dan Kurniawan (2015), kontaminan logam dalam minyak pelumas bekas pada proses pemurnian dengan asam akan bereaksi membentuk larutan garam. Larutan garam memiliki densitas lebih tinggi dari pelumas, sehingga terbentuk endapan di dasar larutan. Salah satu reaksi kontaminan logam ketika proses acid treatment:

$$
2 \mathrm{Fe}_{(\mathrm{aq})}+3 \mathrm{H}_{2} \mathrm{SO}_{4(\mathrm{l})} \rightarrow 3 \mathrm{H}_{2(\mathrm{~g})}+\mathrm{Fe}_{2}\left(\mathrm{SO}_{4}\right)_{3(\mathrm{~s})} \downarrow
$$

Pada dasarnya pelumas murni pada pengolahannya dari minyak mentah (crude oil) memiliki warna dasar coklat kemerahan yang kemudian diolah untuk mengubah warna tersebut menjadi jernih. Pada tahap pemurnian pelumas bekas dengan penambahan asam sulfat (acid treatment). Asam sulfat memiliki sifat dapat bekerja menurunkan tegangan permukaan cairan, sehingga dapat digunakan dalam menghilangkan sejumlah kontaminan yang terkandung dalam minyak pelumas bekas. Tahap acid treatment ini memudahkan tahap adsorpsi karena telah mengurangi kontaminan.

\section{Pemurnian dengan Metode Adsorpsi serta Optimasi Konsentrasi Bentonit dan Suhu Adsorpsi}

Minyak pelumas hasil pemurnian menggunakan asam sulfat pekat, kemudian dimurnikan kembali menggunakan bentonit. Bentonit mempunyai muatan negatif pada permukaannya, sehingga memungkinkan terjadinya reaksi pertukaran ion. Muatan negatif pada permukaan bentonit dapat menarik kationkation dengan gaya elektrostatik. Reaksi pertukaran kation dalam bentonit dapat terjadi karena substitusi isomorfous atom Al dalam lembar oktahedral. Pertukaran kation hanya bisa dilakukan pada kation yang terletak diantara lapisan, supaya tidak mempengaruhi struktur silika-alumina (Yulianto, 2008). Masuknya kation ke dalam ruang antarlapis struktur bentonit, pada dasarnya merupakan ion penyeimbang muatan negatif. Kation tersebut dapat dipertukarkan dengan kation lain yang mempunyai ikatan lebih kuat. Kekuatan pertukaran ion adalah $\mathrm{Na}^{+}<\mathrm{K}^{+}<\mathrm{Ca}^{2+}<\mathrm{Mg}^{2+}<$ $\mathrm{NH}_{4}{ }^{+}$yang berarti kation $\mathrm{NH}_{4}{ }^{+}$dapat menukar ion-ion $\mathrm{Na}^{+}, \mathrm{K}^{+}, \mathrm{Ca}^{2+}$, dan $\mathrm{Mg}^{2+}$ (Grim, 1968).

Penggantian atom valensi positif rendah terhadap atom valensi lebih tinggi, mengakibatkan terjadinya kekurangan muatan positif atau terjadi kelebihan muatan negatif. Kelebihan muatan negatif pada lapisan ini menyebabkan adanya adsorpsi permukaan lapisan terhadap kation. Muatan yang terbentuk bisa disetimbangkan melalui adsorpsi kation yang masuk ke dalam ruang interlamellar. Kation dengan valensi lebih rendah diadsorpsi kurang kuat dan tidak efisien, dari pada kation dengan valensi lebih besar. Tetapi hal ini tidak bisa terjadi pada ion hydrogen karena sifat-sifat hidrasinya yang tidak tentu (Foth, 1988).

Pertukaran kation merupakan proses dimana kation dari larutan bertukar dengan kation yang berada pada interlayer dari bentonit. Interlayer pada bentonit terdiri dari kationkation yang mudah dipertukarkan. Substitusi isomorf pada permukaan bentonit misalkan $\mathrm{Si}^{4+}$ dengan $\mathrm{Al}^{3+}$ pada lapisan tetrahedral, $\mathrm{Al}^{3+}$ oleh $\mathrm{Mg}^{2+}$ pada lapisan oktahedral, menyebabkan kelebihan muatan negatif pada permukaannya. Muatan negatif ini dapat diseimbangkan dengan melakukan adsorpsi kation ke dalam interlayer dari bentonit, atau dengan mensubstitusi balik menggunakan kation yang bermuatan lebih (Kloprogge, 1998). Kation-kation yang dapat dipertukarkan dengan kation yang berada pada interlayer antara lain kation logam maupun kation non logam, misalnya $\mathrm{H}_{3} \mathrm{O}^{+}, \mathrm{NH}_{4}{ }^{+}, \mathrm{Al}^{3+}$, dan $\mathrm{Fe}^{3+}$. Syarat kation yang dapat dipertukarkan dengan kation lain adalah memiliki ikatan yang kuat (Reddy et al., 2002).

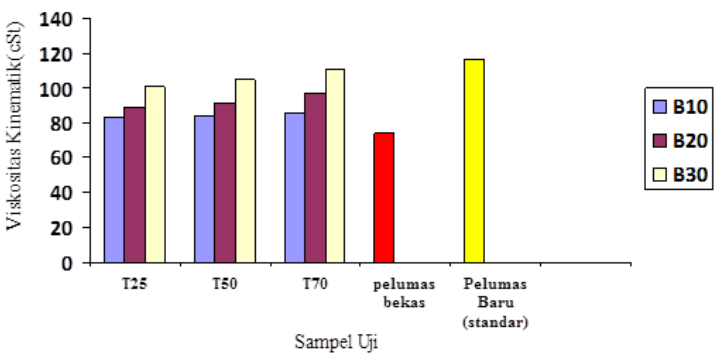

Gambar 3. Viskositas Kinematik pada Suhu $40^{\circ} \mathrm{C}$

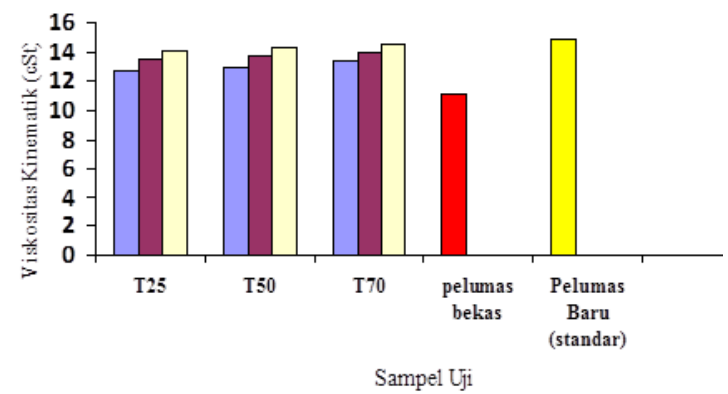

Gambar 4. Viskositas Kinematik pada Suhu $100^{\circ} \mathrm{C}$

Pada proses adsorpsi pelumas bekas dengan menggunakan bentonit, terjadi proses pertukaran kation pada bentonit, sehingga pengotorpengotor logam dan non logam yang belum terlarutkan dalam proses acid treatment dapat 
teradsopsi oleh bentonit. Proses adsorpsi dilakukan dengan memvariasikan bobot bentonit dan suhu adsorpsi.

\section{Viskositas Kinematik}

Pengujian parameter viskositas kinematik dilakukan pada dua suhu yaitu $40{ }^{\circ} \mathrm{C}$ dan 100 ${ }^{\circ} \mathrm{C}$, karena pada aplikasi pelumas di dalam mesin bekerja pada dua suhu yaitu suhu rendah dan suhu tinggi. Oleh karena itu perlu dilakukan pengujian viskositas kinematik pada suhu $40{ }^{\circ} \mathrm{C}$ dan $100{ }^{\circ} \mathrm{C}$ untuk mengetahui kekentalan pelumas pada suhu rendah dan suhu tinggi. Hasil pengujian viskositas kinematik dapat dilihat pada Gambar 3 dan 4.

Data viskositas kinematik pada suhu $40{ }^{\circ} \mathrm{C}$ dan $100{ }^{\circ} \mathrm{C}$ didapatkan bahwa semakin banyak bentonit yang digunakan dan semakin tinggi suhu adsorpsi pada minyak pelumas maka semakin besar nilai kenaikan viskositas kinematik dari minyak pelumas hasil daur ulang. Perubahan viskositas kinematik tertinggi pada variasi campuran B30T70 sebesar 109,92 cSt untuk suhu $40^{\circ} \mathrm{C}$ dan $14,57 \mathrm{cSt}$ untuk suhu $100^{\circ} \mathrm{C}$, dengan $\%$ efisiensi kenaikan viskositas kinematik sebesar $49,15 \%$ untuk suhu $40^{\circ} \mathrm{C}$ dan $30,79 \%$ untuk suhu $100^{\circ} \mathrm{C}$. Hal tersebut menandakan bahwa tingginya nilai kontaminan yang dapat diserap pada variasi campuran ini, sehingga mampu meningkatkan kekentalan pada sampel hasil pemurnian. Jika dilihat dari nilai viskositas kinematik dari minyak pelumas bekas adalah $73,74 \mathrm{cSt}$ untuk suhu $40^{\circ} \mathrm{C}$ dan $11,14 \mathrm{cSt}$ untuk suhu $100^{\circ} \mathrm{C}$ dan nilai viskositas kinematik standar yaitu $116,35 \mathrm{cSt}$ untuk suhu $40^{\circ} \mathrm{C}$ dan 14,85 untuk suhu $100^{\circ} \mathrm{C}$, maka didapatkan hubungan antara viskositas minyak pelumas bekas dengan kontaminan adalah semakin rendah nilai viskositas kinematik minyak pelumas bekas maka akan semakin tinggi pula nilai kontaminan pada minyak pelumas bekas.

Viskositas kinematik minyak pelumas bekas dipengaruhi oleh logam dalam minyak pelumas bekas. Perubahan atau penurunan viskositas kinematik tertinggi pada campuran B30T70 sebesar $109,94 \mathrm{cSt}$ untuk suhu $40^{\circ} \mathrm{C}$ dan 14,57 untuk suhu $100^{\circ} \mathrm{C}$ dapat dijadikan standar penurunan viskositas kinematik optimal dikarenakan nilai viskositas kinematik ini yang paling mendekati dengan standar

\section{Indeks Viskositas}

Kekentalan zat cair biasanya akan menurun bila terjadi kenaikan suhu. Nilai indeks viskositas menunjukkan kemampuan pelumas mempertahankan kekentalan-nya terhadap perubahan suhu (Harjono, 2001). Semakin tinggi angka indeks minyak pelumas, maka semakin kecil perubahan viskositasnya pada penurunan atau kenaikan suhu. Hal ini menunjukkan bahwa bahan dasar pelumas hasil perolehan kembali memiliki kestabilan kekentalan yang tinggi. Hasil pengujian indeks viskositas dapat dilihat pada Gambar 5.

Berdasarkan data indeks viskositas diperoleh hasil bahwa semakin banyak bentonit yang digunakan dan semakin tinggi suhu adsorpsi pada minyak pelumas maka semakin rendah nilai indeks viskositas dari minyak pelumas hasil daur ulang. Penurunan indeks viskositas tertinggi pada campuran B30T70 sebesar 136 dapat dijadikan standar indeks viskositas optimal dikarenakan nilai indeks viskositas ini yang paling mendekati dengan standar yaitu 132 .

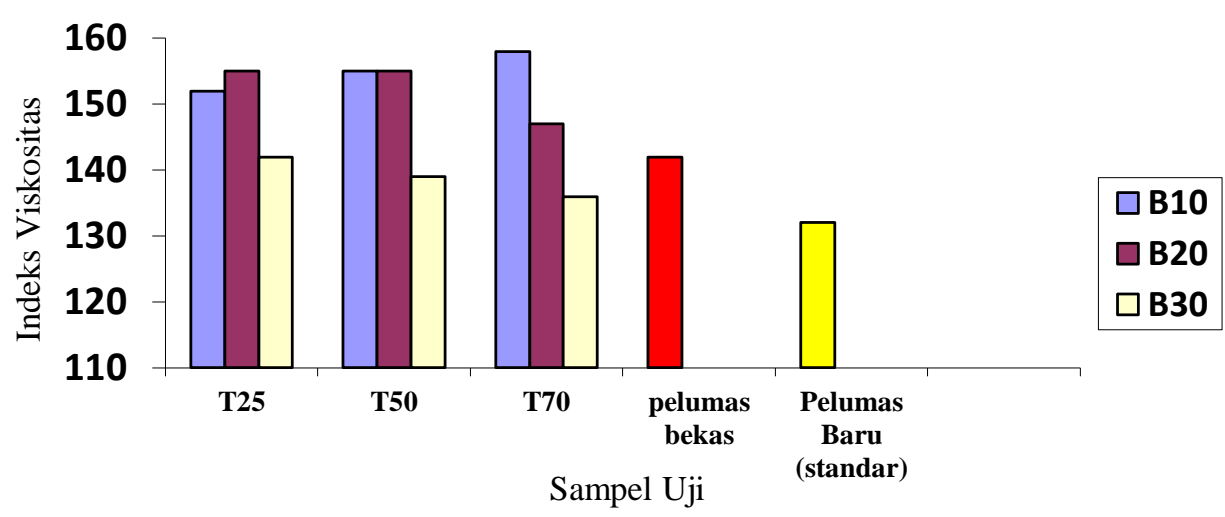

Gambar 5. Indeks Viskositas 


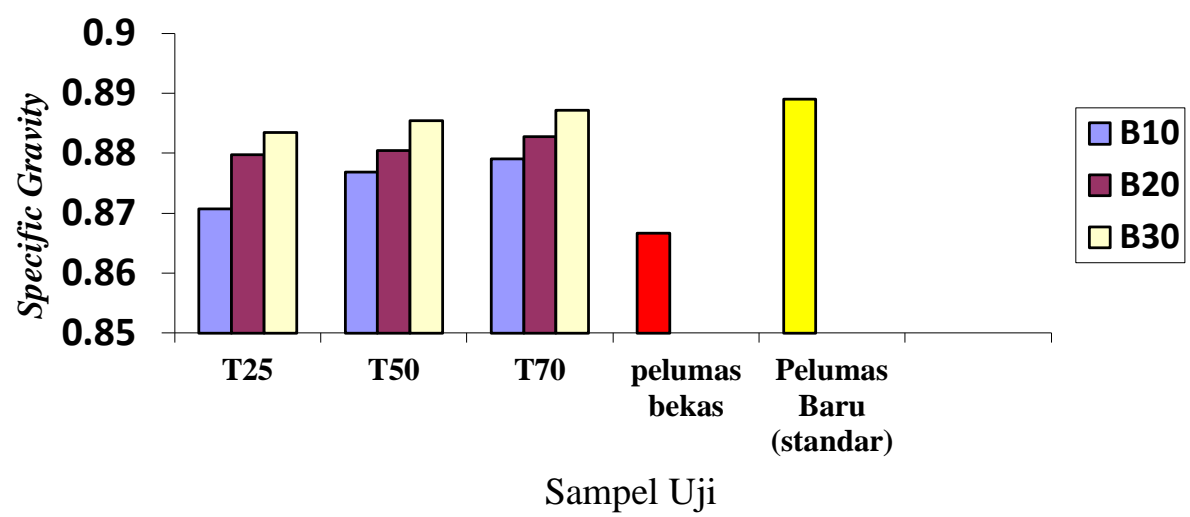

Gambar 6. Specific Gravity $15^{\circ} \mathrm{C}$

\section{Specific Gravity}

Pengujian kualitas pelumas bekas, specific gravity menjadi tolak ukur dalam pengurangan nilai kontaminan, semakin mendekati standar nilai massa jenis minyak pelumas, maka semakin banyak kontaminan yang dihilangkan. Hasil pengujian specific gravity dapat dilihat pada Gambar 6.

Nilai specific grafity pada $15{ }^{\circ} \mathrm{C}$ dari Meditran SX SAE 15W-40 CH-4 adalah 0,8890 dan specific gravity dari pelumas bekas 0,8667 . Berdasarakan data hasil pengujian diperoleh bahwa campuran B30T70 paling mendekati dengan nilai standar dengan hasil 0,8872 . Oleh karena itu, campuran B30T70 merupakan hasil yang paling optimal dikarenakan nilai specific gravity paling mendekati dengan standar.

\section{Warna}

Pengujian warna bertujuan untuk menentukan warna visual dari minyak pelumas bekas yang dihasilkan dan dibandingkan dengan minyak pelumas murni. Tingkat kejernihan warna dari yang terendah ke tertinggi adalah D8,0-L0,5. L adalah singkatan dari light, dan D adalah singkatan dari too dark menandakan bahwa kejernihan warna dari minyak pelumas terdeteksi melampaui batas terendah kejernihan warna. Hasil pengujian warna dapat dilihat pada Gambar 7.

Bentonit sebagai adsorben mengikat sisa karbon dan warna gelap dari minyak pelumas hasil dari proses acid treatment dan diendapkan ke dasar larutan. Perubahan warna pada minyak pelumas sebagian besar terjadi pada proses adsorpsi. Pada campuran B30T25, B30T50, dan B30T70 menghasilkan warna L5,0 yang paling mendekati dengan warna standar yaitu 4,0. Pada pengujian warna, suhu adsorpsi tidak terlalu mempengaruhi hasil yang diperoleh. Hal ini dapat terjadi karena besarnya rentang pengukururan warna pada ASTM D1500, sehingga warna yang dihasilkan tidak dapat terlihat dengan lebih spesifik. Namun, konsentrasi bentonit berpengaruh untuk menghasilkan warna yang lebih jernih. Semakin banyak konsentrasi bentonit, semakin jernih warna yang dihasilkan. Oleh karena itu, campuran B30T25, B30T50, dan B30T70 merupakan hasil yang paling optimal karena merupakan warna yang paling mendekati dengan standar.

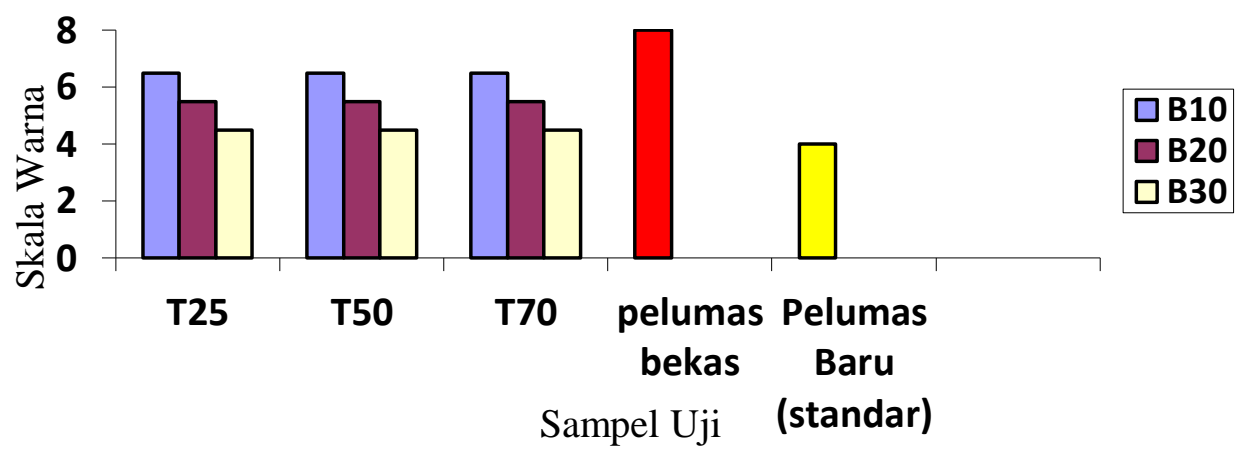

Gambar 7. Warna Minyak Pelumas 


\section{KESIMPULAN}

Konsentrasi bentonit sebagai adsorben dan suhu adsorpsi berpengaruh dalam pemurnian minyak pelumas bekas. Konsentrasi bentonit optimum adalah $30 \%$ dan suhu adsorpsi optimum adalah $70{ }^{\circ} \mathrm{C}$, menghasilkan \% efisiensi kenaikan viskositas sebesar $49,15 \%$ untuk suhu $40{ }^{\circ} \mathrm{C}$ dan $30,79 \%$ untuk suhu $100{ }^{\circ} \mathrm{C}$. Karakteristik minyak pelumas yang dihasilkan yaitu: viskositas kinematik $40{ }^{\circ} \mathrm{C}$ dan $100{ }^{\circ} \mathrm{C}$ sebesar 109,94 cSt dan 14,57 cSt; indeks viskositas sebesar 136; specific gravity $15{ }^{\circ} \mathrm{C}$ sebesar 0,8872 ; serta warna yang dihasilkan adalah L5,0.

\section{DAFTAR PUSTAKA}

Anton, L. (1985). Teknologi Pelumas. Lembaran Publikasi Lemigas PPTMGB Lemigas. Jakarta.

ASTM D445-15. (2017). Standard Test Method for Kinematic Viscosity of Transparent and Opaque Liquids (The Calculation of Dynamic Viscosity). Annual Book of ASTM Standards.

ASTM D2270-10. (2016). Standar Practice for Calculating Viscosity Index at $40^{\circ} \mathrm{C}$ dan $100^{\circ} \mathrm{C}$. Annual Book of ASTM Standards.

ASTM D4052-11. (2017). Test Method for Density, Relative Density, and API Gravity of Liquids by Digital Density Meter. Annual Book of ASTM Standards.

ASTM D 1500-12. (2017). Test Method for ASTM Color of Petroleum Product (ASTM Color Scale). Annual Book of ASTM Standards.

Foth, H.D. (1988). Dasar-dasar Ilmu Tanah. Gajahmada University Press. Yogyakarta.

Grim, R.E. (1968). Clay Mineralogy. McGrawHill Book Company. New York.
Harjono, A. (2001). Teknologi Minyak Bumi. Gadjah Mada University Press. Yogyakarta.

Hilyati dan B. Widihastono. (1991). Adsorpsi Zat Warna Tekstil Pada Zeolit Alam Daribayah. Puslitbang Kimia TerapanLLPL Puspiptek. Serpong.

Joseph U. (2010). A Comparative Study of Recycling of Used Lubrication Oils Using Distillation, Acid and Activated Charcoal with Clay Methods. $J$ Petroleum \& Gas Eng. Vol. 2, No.2, 1219.

Kloprogge, J.T. (1998). Synthesis of Smectites and Porous Pillared Clay Catalysts : A review. J. Porous Mater. 5, 5-41.

Komadel. (2003). Chemically Modified Smectities. Slovac Academy of Sciences. Slovakia.

Kusumah, A. M. (2013). Perolehan Kembali Bahan Dasar Pelumas dari Limbah Pelumas Mesin dengan Metode Adsorpsi dan Penciriannya. (Skripsi). Fakultas Matematika dan Ilmu Pengetahuan Alam. IPB. Bogor.

Lianna, J., Karyati. Y., \& Santosa, H. (2012). Penjernihan Minyak Pelumas Bekas dengan Metode Penjerapan Suatu Usaha Pemanfaatan Kembali Minyak Pelumas Bekas sebagai Base Oil. Jurnal Teknologi Kimia dan Industri. Vol.1, No.1, 252-257.

Mahmudha, S \& Irwan, N. (2015). Pengaruh Penggunaan Bentonit Teraktivasi Asam Sebagai Katalis Terhadap Peningkatan Kandungan Senyawa Isopulegol Pada Minyak Sereh Wangi Kabupaten Gayo Lues - Aceh. Fakultas Matematika dan Ilmu Pengetahuan Alam. UIN Yogyakarta. Yogyakarta.

Mara, I.M., \& Kurniawan, A. (2015). Analisa Pemurnian Minyak Pelumas Bekas dengan Metode Acid And Clay. Jurnal Teknik Mesin. Universitas Mataram. Mataram. 
Mukhlishoh, I. (2008). Pengelolaan Limbah Oli B3 Bengkel Resmi Kendaraan Bermotor Roda Dua Di Surabaya Pusat. (Skripsi). Institut Teknolgi Sepuluh Nopember. Surabaya.

Purwaningsih, H. (2002). Pembuatan Alumina dari Kaolin dan Studi Katalisis Heterogen untuk Sintesis Vanili dari Eugenol Minyak Gagang Cengkeh. (Tesis). Fakultas MIPA. UI. Depok.

Reddy, R. B, Nagendrappa, Y.S., Gopalpur, Prakash, \& Jai, B.S. (2008). Bronsted and Lewis Acidity of Modified
Montmorillonite Clay Determined by FT-IR. Catalyst Today.

Tan, K.H. (1992). Dasar-dasar Kimia Tanah Edisi Pertama. Penerjemah: Goenadi, D.H. Gadjah Mada University Press. Yogyakarta.

Yulianto, A. (2008). Pembuatan Lempung Terpilar Al13 dari Lempung Alam Turen malang untuk Adsorbsi Ion $\mathrm{Pb}^{2+}$. (Skripsi). Departemen Kimia. FSAINTEK. Universitas Airlangga. Surabaya. 